

\title{
Urban Urgency for Air Quality and E-Vehicles: A Case of Prishtina
}

\author{
Bujar Bajçinovci $^{1}$, Mejreme Bajçinovci ${ }^{2^{*}}$ \\ ${ }^{1}$ University of Prishtina, Faculty of Civil Engineering and Architecture, Kosovo. \\ ${ }^{2}$ National Institute of Public Health, Prishtina, Kosovo. \\ Email:mirebaj@yahoo.com,bujar.bajcinovci@uni-pr.edu
}

\begin{abstract}
:
The shortcoming of a sustainable urban mobility plan for the city of Pristina and its linkage to spatial plans in the future will bring serious problems for the city, which will have a negative impact on the quality of life. It is clear that the factual situation of parking spaces in Pristina is problematic. The need for parking spaces and public parking garages in Prishtina are very immediate. There is no parking plan where there are legal, private parking, illegal parking lots. The current degraded state of environment and urban fabric requires specific responsibilities and activities, especially when the state is directly linked to the quality of life and public health. Potential measures for a healthier environment in public parking spaces, requires underground building concepts, thus, accommodating E-Vehicles, and include a diversity of sustainable system solutions.
\end{abstract}

Key words: Prishtina, Parking Spaces, E-Vehicles, Spatial Organization, Urban design.

\section{INTRODUCTION}

The shortcoming of a sustainable urban mobility plan for the city of Pristina and its linkage to spatial plans in the future will bring serious problems for the city, which will have a negative impact on the quality of life. Lack of a serious and professional approach to sustainable city planning, uncontrolled expansion and without scientific determined criteria [1]. With the enormous number of gravitated vehicles and the lack of parking spaces and facilities, almost every neighborhood in Pristina is in the mental state of protecting the parking space [1]. "Cities are complex ecosystems with specific phenomenon's directly reflected in our health, natural resources, economic, social and aesthetic fields. They are open integrated systems and huge organisms with specific and complex metabolism that transform vast amount of energy, generate huge amount of waste and emanate a number of specific environmental phenomenon's and activities" [2]. 
Urban expansion of city development presents a spatial framework, aiming to achieve a better quality of life, with primary features that affect air quality and health wellbeing [2]. According to World Health Organization, Europe, "The epidemiological and toxicological evidence on the effects of transport related air pollution on health has increased substantially in recent decades. Although this includes epidemiological and toxicological evidence, it is only a fraction of the total evidence on the effects on health of urban air pollution. A review of this evidence indicates that transport related air pollution contributes to an increased risk of death, particularly from cardiopulmonary causes" [3, 2]. Furthermore, "Outdoor concentrations of traffic-related air pollutants (nitrogen dioxide PM2.5, particles with a 50\% cut-off aerodynamic diameter of $2.5 \mathrm{~mm}$ and soot) were assigned to birthplace home addresses with a land-use regression model. They were linked by logistic regression to questionnaire data on doctor-diagnosed asthma, bronchitis, influenza and eczema and to self-reported wheeze, dry night-time cough, ear/nose/throat infections and skin rash" $[4,2]$. Free parking space! This is the most elementary urban need nowadays! Furthermore, there is a lot of stress finding the free parking lot, especially when we have to park after a hard labor day in the vicinity of our residential area, there are increasing number of incidents as a result for finding the free parking space, most of the time the Kosovo Police has had to intervene [1].

\section{MATERIALS and METHODS}

The study presented in this paper investigated the Prishtina City, focusing on Urban Planning issues, traffic problems, air pollution and free parking spaces. The research methods consist of empirical observation through field, and literature review. In order to receive a clearer data and information's, research is made within spatial regulation, shapes of architectural models, focusing on the bioclimatic features regarding to the morphology of the city of Prishtina, urban planning, environmental pollution, and issues of public health. The data collected include maps, composition of urban structure, and attributes of space, dimensions of location and traffic activities. The additional data for this paper is based on the analysis of the Municipality of Prishtina archives [1, 2] 
Table 1. Vehicle registration of 2014-2017- Kosovo [5, 1].

\begin{tabular}{l|lllll} 
& 2014 & 2015 & 2016 & 2017 & Grow 2014-2017 \\
\hline Vehicles & 236145 & 281847 & 260291 & 273862 & $+8 \%$ \\
\hline Trans vehicle, 3.5 and over 3.5 Mt & 15769 & 18330 & 17963 & 2735 & $-73 \%$ \\
\hline Trans truck, under 3.5 Mt & 26949 & 30846 & 31285 & 288 & $-935 \%$ \\
\hline Minibus & 3161 & 3212 & 2841 & 1690 & $-47 \%$ \\
\hline Buses & 1697 & 2124 & 1916 & 523 & $-60 \%$ \\
\hline Motorcycles & 1540 & 1849 & 1790 & 2535 & $+64 \%$ \\
\hline Tractors & 1036 & 941 & 613 & 1949 & $+88 \%$ \\
\hline Trailer under 3.5 Mt & 250 & 286 & 288 & 32299 & $+1290 \%$ \\
\hline Trailer 3.5 and above 3.5 Mt & 2281 & 2707 & 2628 & 18559 & $+813 \%$ \\
\hline Total & 288828 & 342142 & 319615 & 334440 & $+86 \%$
\end{tabular}

According to the data presented in Table 1, it is clear that the number of registered vehicles is increasing every year. Lack of additional data such as the year of production, combustion model, producer, origin of the state, does not allow us to find out why this growth trend is happening. Actually, there are increasing number of traffic incidents, altogether also as a result for finding the free parking space. Kosovo Police, through the report of incidents has recorded 49 traffic accidents have been reported across Kosovo within 24 hours, with 24 of them being with injuries. Statistics from this report show that were also a large number of traffic tickets, where the Kosovo Police imposed a total of 849 tickets, Table 2.

Table 2. Daily Report of Kosovo Police for September.1.2019.

\begin{tabular}{l|ll} 
& \multicolumn{2}{|l}{ - } \\
\hline Accidents with Fatality & 0 & - \\
\hline Accidents with Injuries & 24 & - \\
\hline Accidents without Injuries & 25 & 849 \\
\hline Traffic tickets & - & 849
\end{tabular}




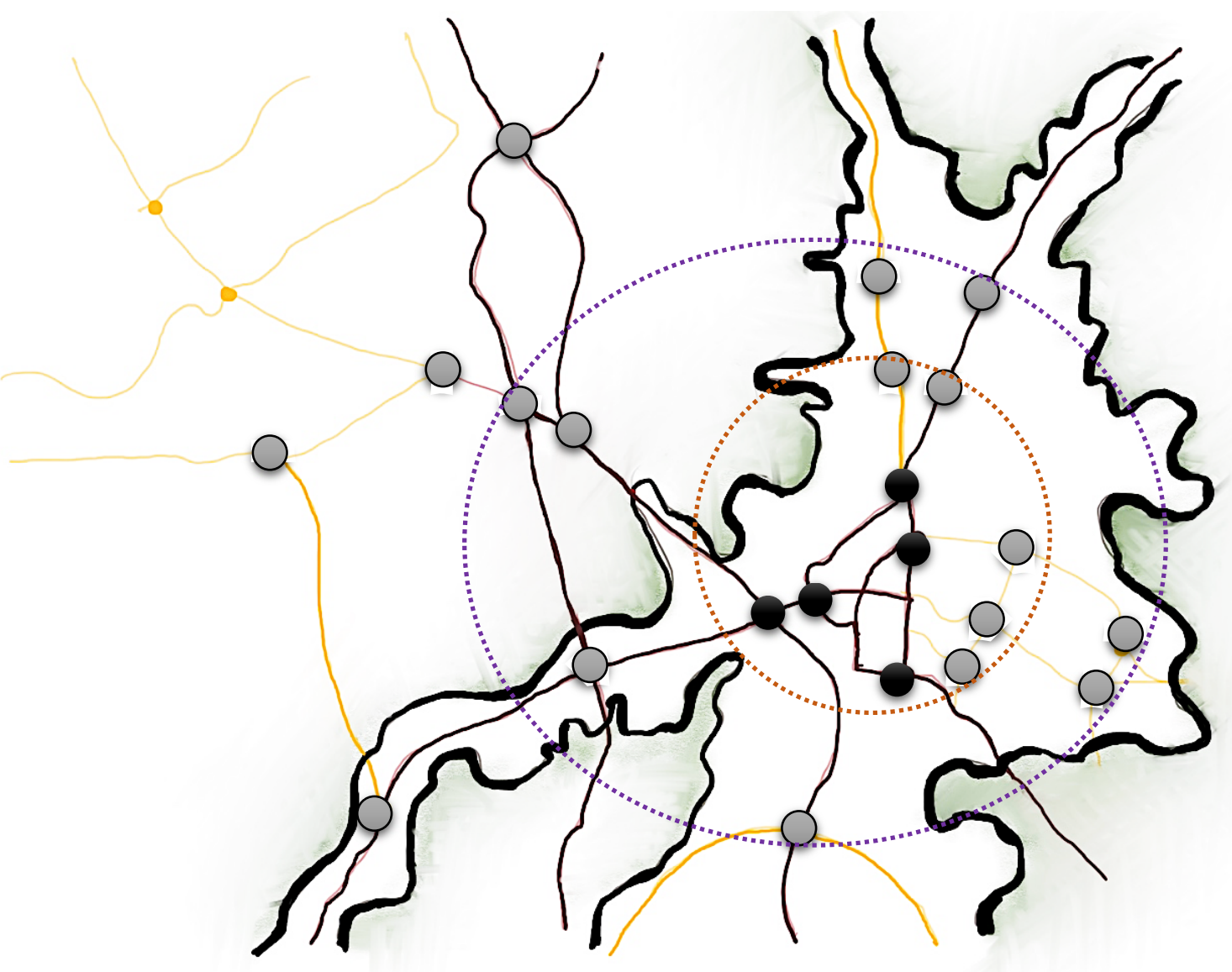

Figure 1. Prishtinas-urban zones, with a drastic requirement for parking spaces. [Authors, 2019]

As we can see in Figure 1, there is a conceptual urban strategy to offer a variety of public parking garages, instead only one and big architectural structure, also, there is need that those type of buildings blend in within an urban composition, preferably incorporated or isolated with a cultivated vegetation. As from urban planning concepts we stand that in those situations, a more suitable are hybrid structures, moreover, parking garages can be realized underground with a closed type of garage. Naturally, those types of architecture structures demand a heavy mechanical ventilation, always preferring the necessity for E-Vehicles as new environmental standard, hence, implementing a new contemporary technology as answer regarding to air pollution [2]. 

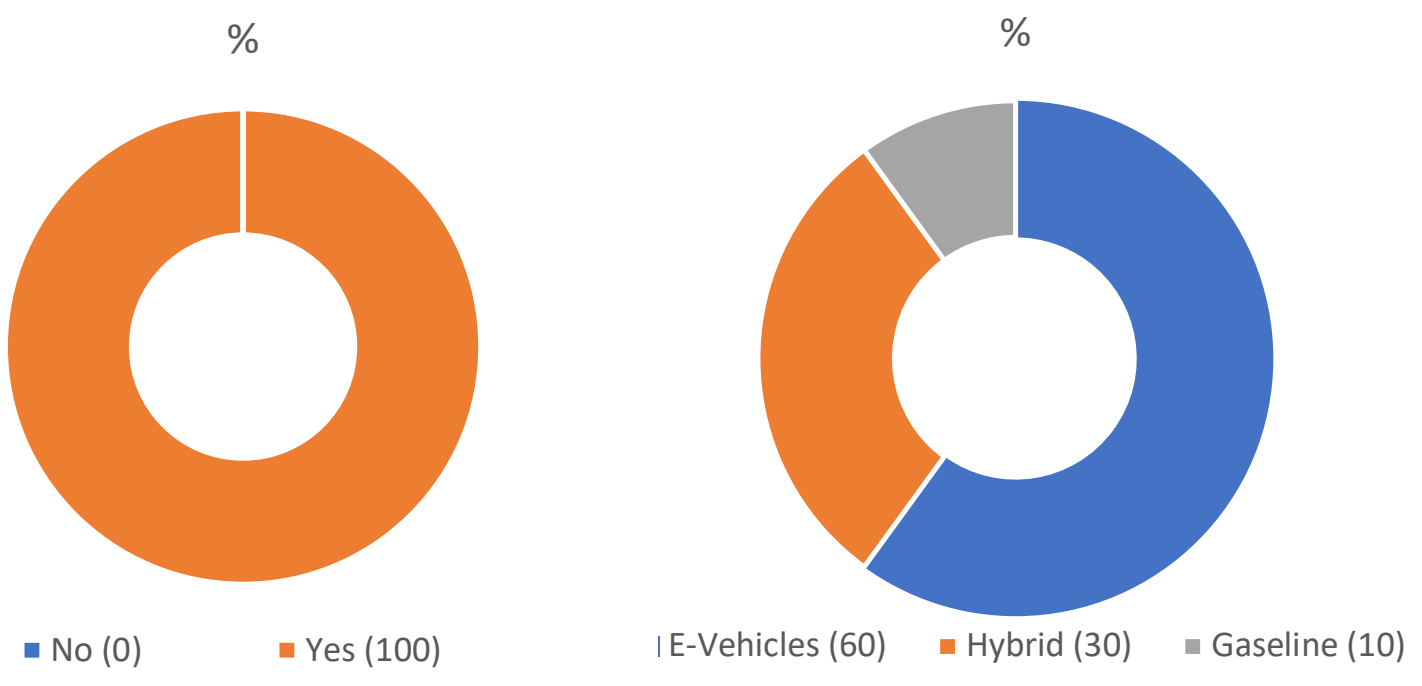

Figure 2. Chart and result from Community Surveys:

a). Do you think gasoline drived vehicles are the main cause of air pollution in Prishtina?

b). Which of the vehicles would you most prefer, Electric, Hybrid, or Gaseline?

\section{DISCUSSION}

The need for parking spaces and public parking garages in Prishtina are very immediate, moreover, the sustainable urban and architectural design is facing major challenges as a result of many contemporary factors: heavy traffic, air pollution, life style, and economy. On the other hand, Kosovo is also participating in global trends, a process by which regional economies, societies and cultures are integrated through a global network [1].

In January 2017, "Prishtina has again experienced heavy air pollution at a significant and very dangerous amount, according to the recent monitoring through AQI-Air Quality Index [6]. Moreover, the city of Prishtina have continuously raised values of air pollution in this season every year, in the last decades. Nevertheless, the heavy worsening of the air quality has been effectual to the most citizens those days, surely, public health deterioration continues to remain one of the vital worries of the households, they are in constant worry for their children health" [7]. 
Table 3. Measured Values For AQI, Pm2.5 In Prishtina, 2017 [6, 7].

\begin{tabular}{l|c|c|c}
$\begin{array}{l}\text { Per Month } \\
{\left[\mathbf{P M} \mathbf{2}_{\mathbf{5}}\right]}\end{array}$ & $\begin{array}{c}\text { The maximum value } \\
\text { of }[\mathbf{A Q I}]\end{array}$ & $\begin{array}{c}\text { The maximum amount } \\
\text { for an hour }\left[\boldsymbol{\mu g} / \mathbf{m}^{\mathbf{3}}\right]\end{array}$ & $\begin{array}{c}\text { Date of maximum value } \\
\text { [Date] }\end{array}$ \\
\hline January & 532 & 600 & 29.01 .2017 \\
\hline February & 259 & 265 & 22.02 .2017 \\
\hline March & 177 & 146 & 02.03 .2017 \\
\hline April & 166 & 122 & 14.04 .2017 \\
\hline May & 108 & 50 & 01.05 .2017 \\
\hline June & 87 & 31 & 01.06 .2017 \\
\hline July & 70 & 23 & 16.08 .2017 \\
\hline August & 82 & 29 & 10.09 .2017 \\
\hline September & 72 & 31 & 18.10 .2017 \\
\hline October & 156 & 83 & 21.11 .2017 \\
\hline November & 241 & 226 & 07.12 .2017
\end{tabular}

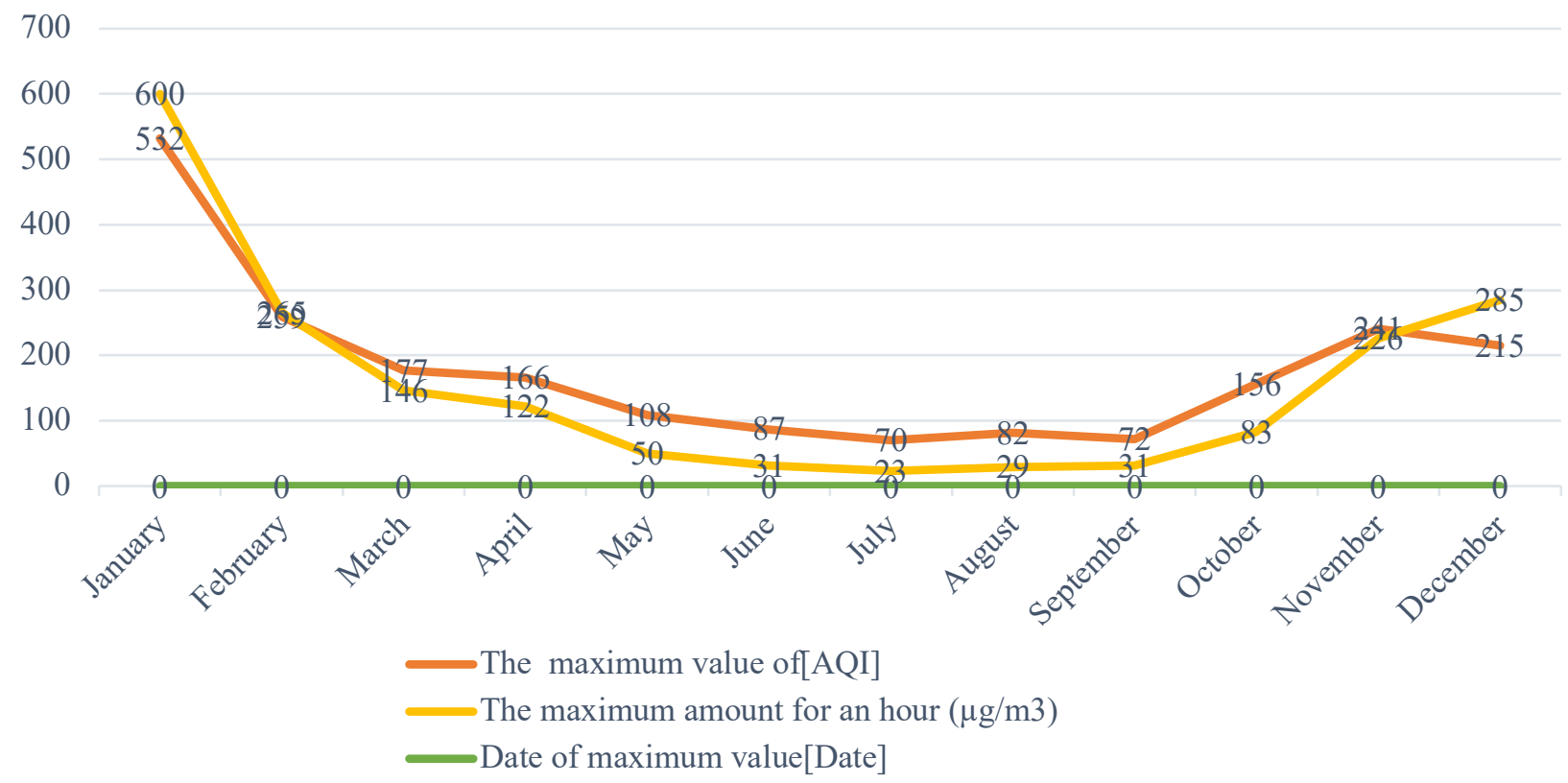

Figure 3. Chart of measured values for AQI, PM2.5 in Prishtina, 2017, [7]. 
Table 4. Values of AQI, the levels of health concern. Adapted, [6].

\begin{tabular}{|c|c|c|}
\hline $\begin{array}{l}\text { Air Quality Index } \\
\text { Levels of Health } \\
\text { Concern }\end{array}$ & $\begin{array}{l}\text { Numerical } \\
\text { Value AQI }\end{array}$ & Meaning \\
\hline Good & 0 to 50 & $\begin{array}{l}\text { Air quality is considered satisfactory, and air pollution pose little or no } \\
\text { risk. }\end{array}$ \\
\hline Moderate & 51 to 100 & $\begin{array}{c}\text { Air quality is acceptable; however, for some pollutants there may be a } \\
\text { moderate health concern for a very small number of people who are } \\
\text { unusually sensitive to air pollution. }\end{array}$ \\
\hline $\begin{array}{l}\text { Unhealthy for } \\
\text { Sensitive Groups }\end{array}$ & 101 to 150 & $\begin{array}{c}\text { Members of sensitive groups may experience health effects. The } \\
\text { general public is not likely to be affected. }\end{array}$ \\
\hline Unhealthy & 151 to 200 & $\begin{array}{l}\text { Everyone may begin to experience health effects; members of sensitive } \\
\text { groups may experience more serious health effects. }\end{array}$ \\
\hline Very Unhealthy & 201 to 300 & Health alert: everyone may experience more serious health effects. \\
\hline Hazardous & 301 to 500 & $\begin{array}{l}\text { Health warnings of emergency conditions. The entire population is } \\
\text { more likely to be affected. }\end{array}$ \\
\hline
\end{tabular}

"It is clear that the factual situation of parking lots in Pristina is problematic. There is no parking plan where there are legal, private parking, or illegal parking lots. Some anti-dumping measures have been carried out in the past mainly by using robust measures such as the placement of vegetation and metal bars" [1].

\section{CONCLUSION}

There is a conceptual urban strategy to offer a variety of public parking spaces and parking garages, also there is need that those type of buildings blend in within an urban composition with a cultivated vegetation [1]. According to the research, "The tree species used for the GAIA-urban forestation project were selected, starting from the green Regulations of the City of Bologna and evaluating important factors such as the potential for absorption of pollutants $\left(\mathrm{CO}_{2}\right.$ and $\left.\mathrm{PM}_{10}\right)$, the release of substances volatile and the allergenic specific factors, the first 24 most suitable species have been identified to fulfil this function" $[8,2]$. 
Also, "There is a considerable potential to further develop the beneficial use of vegetation to promote urban environmental quality and citizen health... Trees and shrubs were compared for PM accumulation on the surface" $[9,2]$.

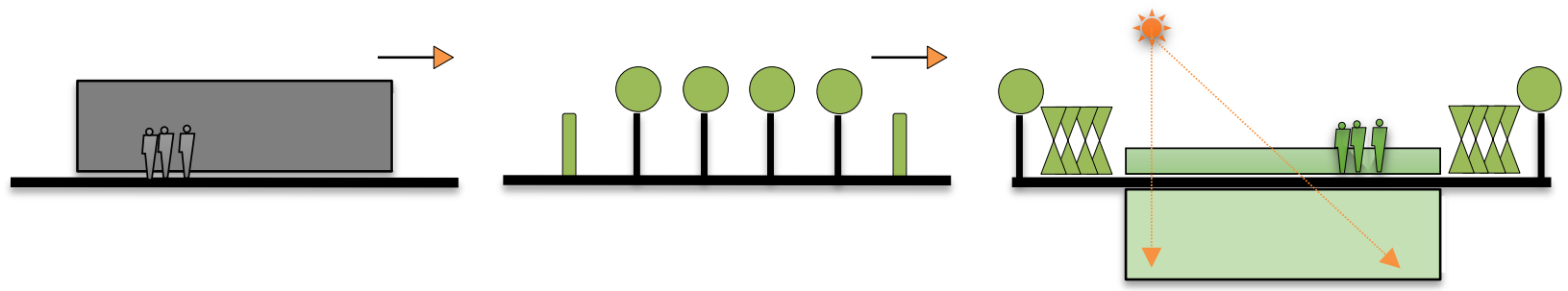

Figure 3. E-Vehicles, Vegetation barriers, Underground parking garages with contemporary environmental solutions for E-Vehicles.

The current degraded state of environment and urban fabric requires specific responsibilities and activities, especially when the state is directly linked to the quality of life and public health. Potential measures for a healthier environment in public parking spaces, requires underground building concepts, thus, accommodating E-Vehicles, and including a diversity of sustainable system solutions.

\section{REFERENCES}

[1] Bajçinovci, B., Bajçinovci, M. (2019). Anxiety and Urban Stress for Parking Spots. Journal of Science, Humanities and Arts. Volume 6, Is. 1. DOI: 10.17160/josha. 6.1.525

[2] Bajçinovci, B., Jerliu, F. (2016). Challenges of Architectural Design in relation to Environment and Air Pollution. A Case study: Prishtina's first public parking garage. Journal of Science, Humanities and Arts. Volume 3, Is. 7. DOI: 10.17160/josha.3.7.254

[3] WHO, Europe, Krzyzanowski et al., Health effects of transport-related air pollution. World Health Organization. Copenhagen, Denmark, 2005.

[4] Brauer, M. et al., Air pollution and development of asthma, allergy and infections in a birth cohort. ERS Journals Ltd 2007, 2007. DOI: 10.1183/09031936.00083406

[5] SAK, 2018. http://ask.rks-gov.net/en/kosovo-agency-of-statistics. $\quad<$ http://askdata.rksgov.net/PXWeb/pxweb/sq/askdata/askdata_Transport/tr05.px/?rxid=a68d80f4-e84a-44b9beb1-661fa7c95768> [Accessed: 4 January 2019].

[6] Environmental Protection Agency, EPA, AirNow US 2017. Air Quality Index [AQI]. Available online: $\quad$ https://airnow.gov/index.cfm?action=airnow.global summary\#Kosovo\$Pristina [Accessed 06.01.2019]. 
[7] Bajcinovci, B. (2019). Environmental and Climate Dilemma: Coal for heating or Clean air for breathing: A case of Prishtina. Environmental and Climate Technologies, Latvia. Sciendo, De Gruyter Press. Vol. 23, no. 1, pp. 41-51 DOI: 10.2478/rtuect-2019-0003

[8] GAIA., Institute of Biometeorology, Bolonia. Baraldi, R., European Life+ project. Trees that can reduce air pollution. 2016. < http://lifegaia.eu/ > [Accessed: 24-August-2016].

[9] Saebo, A. et al., S.W. Characterization of urban trees and shrubs for particulate deposition, carbon sequestration and BVOC emissions, 2013. Acta Hortic. 990, 509-517. DOI: 10.17660/ActaHortic.2013.990.66 